\title{
Trying for better circumstances (Zama Zama): Exploring ubuntu amongst marginalised women in an informal settlement
}

Author:
Retha Kruidenier ${ }^{1}$
Affiliation:
'Department of Practical
Theology, University of
Pretoria, South Africa
Correspondence to:
Retha Kruidenier
Email:
retha@geo-logic.co.za
Postal address:
327, 25th Avenue, Villieria
Pretoria 0186, South Africa
Dates:
Received: 20 Feb. 2015
Accepted: 08 Apr. 2015
Published: 18 June 2015
How to cite this article:
Kruidenier, R., 2015, 'Trying
for better circumstances
(Zama Zama): Exploring
ubuntu amongst marginalised
women in an informal
settlement', Verbum et
Ecclesia 36(2), Art. \#1433,
7 pages. http://dx.doi.
org/10.4102/ve.v36i2.1433
Note:
Research Participant in the
Ubuntu-Research project of
the University of Pretoria.
Copyright:
@ 2015. The Authors.
Licensee: AOSIS
OpenJournals. This work is
licensed under the Creative
Commons Attribution
License.

\section{Author:}

Retha Kruidenier

Affiliation:

Theology, University of

Pretoria, South Africa

\section{Correspondence to}

\section{Email:}

Postal address:

327, 25th Avenue, Villieria Pretoria 0186, South Africa

Received: 20 Feb. 2015

Accepted: 08 Apr. 2015

How to cite this article: Kruidenier, R., 2015, 'Trying for better circumstances ubuntu amongst marginalised women in an informal 7 pages. http://dx.doi.

\section{Note:}

Ubuntu-Research project of

Copyright:

(C) 2015. The Authors.

Licensee: AOSIS

License.
This article explores possible experiences of $u b u n t u$ in the Zama Zama informal settlement. Postfoundational practical theology and the narrative approach function as paradigm and methodology. Themes and/or discourses like poverty, violence, xenophobia and the role of the local church were identified, but $u b u n t u$ is not always visible as a lived reality amongst the members of the community. The church is an exception. Women play a leading role in the congregation and it is in the church where ubuntu values are visible and experienced.

\section{Introduction}

The Second Cluster of the Ubuntu Project of the Centre for the Advancement of Scholarship of the University of Pretoria explores personal and community narratives in order to examine whether the concept of ubuntu is indeed primal in the shaping of identities, and to understand how it interacts with faith traditions. The cluster also explores the impact of ubuntu on spiritual frameworks of African believers, as well as on individual and community levels.

This specific research project takes place in an informal settlement in Pretoria West called Zama Zama. Zama Zama is one of many informal settlements, also known as 'squatter camps', around the City of Tshwane. The coresearchers of the study are selected women that live in Zama Zama. They were selected according to the snowball sampling method.

The study explores the existence, and/or absence, of ubuntu amongst the members of the community. Due to the importance of the contextuality of the research, it is important that the community members should define the meaning of ubuntu amongst themselves. This is an explorative study of the author's first encounters with the relevant women. For Mashau and Kritzinger (2014:12), transformative encounters happen in respectful and sensitive conversations, particularly if the encounters are with people who have been systematically silenced, excluded and marginalised through cultural, religious, political and economic processes.

People living in this informal settlement exist in difficult and poor circumstances and this research project hopes to voice the experiences and concerns of the women living in Zama Zama and examines how their personal narratives of their faith could be used to understand the extent to which ubuntu philosophy underpins their spirituality.

\section{Epistemology and methodology Postfoundational practical theology}

The research was done in postfoundational practical theology according to the seven movements of postfoundational research developed by Múller (2004:300), for practical theology. He adapted the movements from Van Huyssteen's (1997) model:

\begin{abstract}
A postfoundational theology wants to make two moves. First, it fully acknowledges contextuality, the epistemically crucial role of interpreted experience, and the way that tradition shapes the epistemic and nonepistemic values that inform our reflection about God and what some of us believe to be God's presence in this world. At the same time, however, a postfoundationalist notion of reality in theological reflection claims to point creatively beyond the confines of the local community, group, or culture towards a plausible form of interdisciplinary conversation. (p. 4)
\end{abstract}

Postfoundational practical theology should be seen as a way of understanding within the paradigm of the hermeneutical approach, and yet it moves beyond hermeneutics as a metaphor for practical theology. Müller (2004:294) became increasingly critical towards the application of the hermeneutical approach in practical theology, because of to the inadequacy of the approach 
to provide practical theology with real contextual outcomes. It seems to leave practical theology with theoretical abstractions. The 'theories for praxis' thus created often remain distant from the real world.

For Van Huyssteen (2006:22), postfoundational theology is an effort to move beyond the modernistic boundaries of practical theology. It is also an effort to avoid the relativism of antifoundationalist theories. Its initial perspectives are contextual, but its performances transcend the local and the concrete and ultimately facilitate interdisciplinary research and study.

\section{Feminist practical theology}

When doing research with marginalised women as coresearchers, feminist considerations become of central importance. Feminist practical theology is a division of practical theology, with a particular focus on women. It includes women's lives, the diversity of their experiences, and the particular features of their lives that are structured or constrained by a sexist society and theology. It is critical and constructive, based on the conviction of the full humanity of women and is engaged in reconstructing human society, including religious institutions, to reflect women's equality with men (Nicholas 1998:158; Rakoczy 2004:11).

Feminist practical theology links with liberation theology because of the emphasis on the description of people's lived experiences, especially marginalised people and the need for liberation. The method of liberation theology allowed for an interactive process between lived experience and discourses in both society and the church. Feminist practical theologians, like Bons-Storm (1998:6) and Ackermann (1998:94), underline the importance of practical theology in liberating, healing and transformation. If practical theology were about listening and reflection alone, it would be helpless to unsettle the power structures of those more privileged.

Bons-Storm (1998:15) sees practical theology as 'faith lived in context', which combines the following: the context of the Christian tradition in terms of different theologies and its impact in the form of sermons and Christian education, the context in which people live their lives, as well as the quickening work of the Holy Spirit. She believes this communication of the Holy Spirit speaks to the hearts of women who long for a life of abundance as envisioned by God. This communication from God to women empowers them as 'theological agents' and gives them the right to be heard and taken seriously.

\section{Narrative research}

The narrative approach in doing research is used because feminist practical theology is contextual and deal with 'real people's stories':

Stories play a central part in narrative research. Life is a journey

... we all are coming from somewhere, and is heading somewhere

... We all have a past and a future and with stories we are trying to connect the past with the future. Using the narrative metaphor leads us to think about people's lives as stories and to work with them to experience their life stories in ways that are meaningful and fulfilling. (Freedman \& Combs 1996:1)

According to Frank (1995):

Storytelling is for another just as much as it is for oneself. In the reciprocity that is storytelling, the teller offers herself as guide to the other's self-formation. The other's receipt of that guidance not only recognizes, but values the teller. The moral genius of storytelling is that each, teller and listener, enters the space of the story for the other. Telling stories in postmodern times, and perhaps in all times, attempts to change one's own life by affecting the lives of others. (p. 17)

Ellen Kuzwayo was a women's rights activist and politician in South Africa. In her autobiography, Call me women (1985), she told the 'untold' stories of her youth and her struggle with domestic violence; with this publication, she was breaking ground in the African storytelling tradition and participated in telling the South African story in conjunction with other African women. She brought to the force the voice of the African woman that had been silent for so long.

Narrative research seeks to do research in a respectful way and is nonblaming, and centres people as the experts of their personal lives. Narrative conversations are interactive and always in collaboration with the coresearchers.

The narrative researcher deconstructs the sometimes abusiveness of research projects. Narrative researchers want to be researchers who do not pathologise or victimise their narrators. The research must not serve the researcher's objectives, but must be of value for those being researched. The interviewees are treated as partners, or coresearchers. Together the researcher and coresearcher decide what issues to explore, suggest what remains to be said, and work to provide the thick description that builds toward an overall picture (Rubin 1995:11).

Human (2003:41) views narrative research as a form of practical wisdom that values the stories of people and communities, instead of working with hypotheses of what should or might be. The contribution of the researcher is to reflect and facilitate, and to wait until the plot emerges. The aim of the research is not to bring about change, but to listen to the stories and to be drawn into those stories. Subjective integrity and participatory interaction is important for the researcher.

\section{Ethics and the research process}

It was of upmost importance to be ethically responsible in the way I conducted the research and in the way I interacted with the coresearchers. As narrative researcher, it is important to keep in mind that the ethical process is a continuous process throughout the research. I therefore acknowledge my own moral preferences and remain acutely aware of the need to decentre them in order to place myself in a not-knowing position. 
Clandinin and Connelly (2000:169) comment that as we move from 'field text' to 'research text', we must always be ethical in our doings. To be ethical requires more than appealling to current regulations, rules and standards. We must be mindful of the moral quality of the relationships we are inviting, encouraging, fostering and responding to (eds. Carlson \& Erickson 2002:220).

Freedman and Combs (1996:265) show the differences between modern and postmodern approaches to ethics. Modernist ethics tend to be based in rules that can be prescribed and enforced in a 'top down' way. In the postmodern world, ethics focus on particular people in particular experiences, and there is considerable scepticism about the applicability of any kind of sweeping, universal, one-size-fits-all truth claims.

\section{An introduction to the ubuntu discourse}

Because the emphasis of the study is on the existence, and/or the absence of $u b u n t u$ amongst the members of the community of Zama Zama, the ubuntu discourse must be introduced and discussed. Ubuntu is an African concept that gained a lot of interest and attention in the last few years. There are many books and journal articles available on the topic, and many definitions on and perceptions about it. Ubuntu is a prominent notion in the public sphere of the democratic South Africa and in the post-apartheid context a trademark of the 'new' South Africa. Shutte (2001:3) stated that ubuntu is almost the exact opposite of apartheid. Apartheid's key idea is separation, separate development and development through separation. At the centre of ubuntu is the idea that 'umuntu ngumuntu ngabanthu' (isiZulu: 'a person is a person through other persons'), and persons depend on persons to be persons. It is by belonging to the community that we become ourselves. The community is not opposed to the individual, nor does it simply swallow the individual up; it enables each individual to become a unique centre of shared life. Human beings exist and become in relationships with other human beings.

Ubuntu is a concept that is value driven. Values are the basic foundations of each person's view of how life is supposed to be lived and they influence choices, attitudes as well as goals in life. A person with ubuntu is often defined through virtues that reflect an orientation towards other people, like kindness and hospitality.

Desmund Tutu (1999:34) speaks about a 'third way'. What is it that constrained so many to choose to forgive, rather than to demand retribution? According to Tutu (1999:34), it lies in $u b u n t u$. It speaks of the very essence of being human. People with $u b u n t u$ are generous, hospitable, friendly, caring and compassionate: 'They share what they have ... and my humanity is caught up in theirs' (Tutu 1999:34). We belong in a bundle of life. A person with $u b u n t u$ is open and available to others, affirming of others, does not feel threatened that others are able and good; for he or she has a proper self-assurance that comes from knowing that he or she belongs in a greater whole and is diminished when others are humiliated or diminished, when others are tortured or oppressed, or treated as if they were less than who they are.

Gade (2011:303) is making a major contribution by collecting and collating literature on the communalistic nature of ubuntu. According to him (Gade 2011), ubuntu has frequently appeared in writing since at least 1846. In written sources published prior to 1950, ubuntu is always defined as a human quality. At different stages during the second half of the 1900s, some authors began to define ubuntu more broadly: definitions included ubuntu as African humanism, a philosophy, an ethic, and as a worldview. Nyerere (1968:5) used the term 'ujamaa' to refer to the same concept. For him, one of the most socialistic achievements of their society was the sense of security it gave to its members, and the universal hospitality on which they could rely.

For Ngcobo (2014:88), ubuntu is closely related to human dignity. For him, human dignity should find its substance and significance in its interconnectedness with the creation activity as a whole, and refer to the value of creation as a whole. Human dignity is communal, because human beings find their sense of being through being part of the community. It is rooted in living and sharing space. Being a human is being with others. We are born into the community and for the community. Human dignity is not earned and does not rest on prizes or the respect that one has earned.

Human beings maintain their original created nature intended by God, regardless of the condition in which they find themselves. Dignity is encountered and in such a way as to be beyond manipulation; class, race, region or religion never determines it. It is owned and shared by a community. Human dignity should be more embracing of uniqueness and individuality, because the community is made of collective individuals. Therefore, it is part of $u b u n t u$, for it upholds human dignity and life in their totality, belonging to the community as a whole. Human dignity can only find its place within a community.

Koopman (2007:183) supports this view by stating that true humanity is not defined by independence and rationality, but by the willingness to enter into relationships with others. In the interaction with others, an individual finds his or her essence of being. I receive my being from others, and we receive our existence from the hands of the 'other' and my existence is meaningful because there are others who want to share their existence with me.

Müller and Van Deventer (1998:263) see an individual also as a person through the divine; through his or her land, crops and cattle; through his or her house and home; through his or her labour; through health; through wisdom; and in particular, through his or her family. A person's cosmological existence extends beyond space and time and therefore transcends the grave and as such, family relations and relationships are just as important in death as they are in life. 
Despite the differing scholarly approaches to discussing ubuntu, there is a widely shared understanding that the concept constitutes a relational, communal ethic (Hankela 2013:80). It is bound up in the human being's connectedness with other human beings and with an ever-changing and complex world.

Africans should be able to define the question who they are and what they understand of ubuntu by looking through African lenses rather than repeating what has been described by the West. In this case, the vulnerable and marginalised women in Zama Zama should be given a platform to make their voices heard.

\section{The voices of the women}

The 'voices of the women' being listened to are selected women that live in Zama Zama. The conversations took place between the author and the women. The women were selected by snowball sampling. Snowball sampling is also called network sampling, according to Neuman (2014:140). It is a method for identifying and sampling the cases in a network and uses the analogy of a snowball. It begins small, but becomes larger as it is rolled on wet snow and picks up additional snow; it is a multistage technique. Researchers begin with one or a few people or cases and spread out based on links to the initial cases. The crucial feature is that each person or unit is connected with another through a direct or indirect linkage. In the encounters with women in the settlement, the author was introduced to other women. Informal conversations took place over a period of time.

Zama Zama is an informal settlement in Pretoria West, which is a poverty-stricken area. Poverty affects white people, as well as black people living in the area. Zama Zama is one of four informal settlements in the area. Most of the people living in Zama Zama are migrants from African countries. According to the women living here, the name Zama Zama means 'trying' - trying for better circumstances. At first, the squatter camp was located up the hill, but a few years ago, all the people were moved downhill, opposite SA Bricks on Hornsnek Road in Pretoria West. The community favours this new location, as the stands are larger.

In Zama Zama, the dwellings that the people live in are shacks made of zinc, and in most cases, consist of only one room. They live in these 'houses' with their children, and often share it with other families to keep costs as low as possible. They live in very poor conditions with only the basics to try to make a living. These individuals are responsible for the household activities, queue to get some water, and look after their children. Most of them are single mothers, or their partners and husbands work in other cities or on the mines. Some of the men have jobs at SA Bricks, opposite Zama Zama.

They have no access to fresh water on the premises and must wait in long queues with their buckets for a municipal truck to deliver water three times a week. The women wake up early in the morning to try to be first in the queue to get water. Sometimes violence breaks out in these queues, but it is also in these queues that sisterhood is experienced and friendships are formed. They often do not know where their next meal will come from.

The women and their children are also often the victims of violence; sexual abuse, drug and alcohol abuse, domestic violence and robbery are part of their daily lives. As an example, a few years ago, a four-year-old girl was raped. However, the women living in Zama Zama agreed that the violence in the community was less in the past year. The police of Hercules Police Station are often visible in the community and that helps to bring down the incidence of violence.

Most of the people are either unemployed or work once or twice a week. Children do not go to school, because there is no transport available to nearby schools. In addition, children are often left alone for days as the mothers go in search for jobs. Children as young as four years are expected to look after their siblings; their younger siblings therefore become their responsibility. This shows the grim reality of these women's everyday lives and demonstrates the povertyridden plight of so many women and their children.

Out of the conversations I had with these women, the discourses that challenged the actualisation of ubuntu in Zama Zama were violence, poverty and xenophobia. Interdisciplinary investigations revealed the following.

\section{Poverty}

Poverty is often considered as deprivation, a condition marked by the lack of necessities of life; it is the deprivation of basic human needs, which commonly includes food, water, sanitation, clothing, shelter, health care and education. According to Pieterse (2001:30), poverty is the inability of individuals, households or entire communities, to command sufficient resources to satisfy a socially acceptable minimum standard of living. To many people, poverty means not knowing where their next meal is coming from, or fearing eviction from their meager dwellings, because they cannot pay the basic rental. Poverty dehumanises, marginalises and excludes people, and makes them suffer in a holistic way.

According to the Millennium Development Goals Report (United Nations 2013:7), 1.2 billion people are still living in extreme poverty, despite achievements made on the global level in the fight against poverty. In sub-Saharan Africa, the number of people living in extreme poverty rise steadily from 290 million in 1990 to 414 million in 2010, accounting for more than a third of people worldwide who are considered destitute.

Around the world, abject poverty is found in areas where poor health and lack of education deprive people of productive employment, environmental resources have been depleted or spoiled and corruption, conflict and bad governance waste public resources and discourage private investment. (United Nations, 2013:n.p.). 
The picture of poverty in South Africa is overwhelming. Just below $50 \%$ of the population belong to the poorest $40 \%$ of households. In addition, $27 \%$ of the population fall in the bottom $20 \%$ of households and are classified as 'ultrapoor'. Poverty in South Africa is not confined to one racial or ethnic group, but cuts across all groups. The concentration is manifestly higher amongst black people (Pieterse 2001:33). In the City of Tswane, the poverty rate was 38\% in 2001 and $27.9 \%$ in 2014, according to Cronje (ed. 2014); $24.2 \%$ of the general population are unemployed, $32.6 \%$ of the youth are unemployed, and $14.9 \%$ of the population in the City of Tswane have no income.

Janse van Rensburg (2013:1) mentioned that we must see poverty in a holistic way and stresses the fact that psychology plays a significant part in the experience of poverty. In his article, he looks at the inner driving forces of poverty that not only create poverty, but also sustain a situation of poverty. In some cases, all efforts to help an individual, a family or a community break the bonds of poverty are fruitless.

Poverty is a complex amalgam of physical and spiritual pain, which robs the person and the community of dignity and meaning as much as it deprives the body of nourishment, shelter and beauty. It is largely an emotional state. The stigma clinging to poor people is that they are not good enough, which leads to feelings of inferiority and insecurity. Poverty is about exclusion and power, about relationships and loss of self-respect. It is about lack of choice and limitation of freedom (Vorster 2005:652).

\section{Xenophobic experiences}

Xenophobia was a common point of reference in the telling of their stories. A large number of the people living in Zama Zama are migrants from other African countries. The women who came from other countries said that they are used to being exposed to comments 'that are not very nice'. The pastor in the community, a woman from Zimbabwe, mentioned that she heard people gossiping behind her back, and it made it very difficult for her: 'I prayed to God to give me strength to cope and carrying on'.

According to Rugunanan and Smit (2011:706), migration can be described as the movement of people from one area to another, either within their own country or across borders. Migration may be voluntary, where people leave of their own free will, or involuntary, where they are forced to flee, either internally or leaving the country altogether.

The lack of economic opportunities these people experienced in their home countries caused them to come to South Africa in an attempt to improve their lives. Poverty tends to push people into economic migration. Because of their dire need to overcome poverty - and the efforts that people go to escape poverty, including entering South Africa illegally - these women are aware that exploitation might possibly occur. They are exposed to xenophobic actions from local people. Xenophobia is a form of discrimination and the unreasoned fear of that what is perceived to be foreign and strange. In many cases, these perceptions are cultural, and the objects of the phobia are cultural elements that are considered alien. Underlying causes are often linked to economic changes that lead to feelings of fear and insecurity.

Unfortunately, for these foreign people, this destination (instead of providing a safe haven) frequently offers only further traumatisation. These women are constantly worried about their daily survival. Green (2013:134) comments that there have been initiatives since 2008 that have attempted to address xenophobia. However, many people feel that until the economic discrepancies between the rich and poor are addressed, foreign migrants will continue to be 'soft targets' for people's frustrations

Many South Africans have misconceptions that refugees bring with them disease and despair, perpetuate crime, get involved in smuggling and drug trafficking, pilfer jobs and compete for basic services. In stark contrast, a study by Landau, Ramjathan-Keogh and Singh (2005:20) showed that asylum seekers tended to be urbanised, well educated with some form of higher-level education, and multilingual. Many of them are entrepreneurs or worked in specialist positions in their home country. They believe that South Africa is a land of economic opportunity, and the development of informal and foreign owned businesses has created employment opportunities that have breathed new life into innercity areas.

\section{Violence}

Seedat et al. (2014:136) comment that pronounced gendered, age-related, and socioeconomic features mark violent activities. Extensive poverty, prolonged periods of unemployment and income inequality, gender inequality, patriarchal notions of masculinity, exposure to abuse in childhood and compromised parenting, access to firearms, pervasive alcohol misuse, and fragilities in law enforcement are amongst the many factors inherent to the social dynamics of violence.

There is no accurate information available on the incidence of violence in Zama Zama. We can accept that the situation will be in line with the overall situation in South Africa. According to the Official Crime Statistics for 2012/2013 (Africa Check 2013), the most notable aspect of the crime statistics is that violent crimes that cause the most fear and trauma amongst members of the public have increased. There is an increase in both the number and rate of murders and attempted murders. There is also an increase in sexual offences recorded by the police. Cases pertaining to sexual offences increased from 64514 incidents to 66387 incidents, which indicates an increase of $2.9 \%$.

In an article published in Beeld (14 February 2014), Naeemah Abrahamse of the South African Medical Research Council stated that violence against women and children is the highest in Gauteng (38.9\%); statistics of violence against women and children worldwide is also shocking with $45.6 \%$ 
in Africa, South East Asia with 40.2\%, USA, Britain, Japan and Australia 32.7\%.

Traditionally violence has referred to injury resulting from the use of physical force. However, recent critique of feminist and liberation analyses have enlarged the general understanding of violence to include explorations of power and power inequalities (Bower 2014):

We are now at the point of defining violence not only as physical coercion, but also as unjust and abusive use of power as well as the presence of prior restraint that is coercive. (p. 108)

The complex gendered dimension and associated involvement of aggressive masculinities are starkly evident in the rates for both male and female homicides. The patriarchal nature of South African society has an enormous impact on the lives of women and children in South Africa, contributing significantly to perceptions of the roles and rights of women and children, to the high levels of sexual violence, and to the poverty and inequality that characterise their lives (Bower 2014:108).

\section{Spirituality and the role of the African Church}

The conversations I had with the women of Zama Zama show that religion and spirituality hold central places in terms of coping with their realities. Rakoczy (2004:10) mentioned that African women's experience is the starting point when they do theology. It concerns the whole life of every woman, regardless of education and social status, and it is contextual. Through it, women want to assert their belonging to the church (Rakoczy 2004):

First African women do theologies with their bodies: Fetching water over long distances, chopping wood for fire to prepare food for their families, working in the fields - and in the homes of the middle-class and upper class. These actions of care and concern are the first theological voices of African women. (p. 10)

They use their spirituality as a coping resource in difficult times. Spirituality is a highly personal concept that has no clear and concise definition. Spirituality influences every domain of life. It includes understandings of forgiveness, liberation, hope, justice, salvation, the meaning and purpose of life, responses to oppression, interpersonal relationships, choice of romantic partners, definitions of community, physical and psychological well-being and political belief (Bacchus \& Holley 2014:66).

To go to church on Sundays and by attending prayer groups on Wednesday's lifted their spirits. They use formal religious involvement and private devotional practices, like prayer, for inner strength. Their spirituality gives them the grace and strength to deal with their daily issues and challenges. They find the answers to their spiritual and emotional needs by worshipping God. They surrender their emotions, their confusion, as well as the lives of their families and other people to God.
African women have special issues in their lives, like the dangers that usually go with pregnancy, childbirth, menstruation, miscarriage, infant death and being the cause of a childless marriage. Their spirituality helps them to accept the reality of their circumstances, helps them to cope with financial difficulties, illness and psychological distress. By turning things over to God, they feel relieved. They believe that God will answer their prayers. African women are 'programmed to live for others'. They live for their children, family and community, as these constitute the locus of one's worthiness. This, in some cases, has come to mean that women live to please men and pride themselves on being the providers of continuity and the carriers of tradition.

In African women's theology, hospitality is a word that generates the themes of caring, providing, helping, sharing and ministering to the needs of others and most often the concept of mothering. Women experience several traditional practices of hospitality that are accompanied by risk of disease and violence and economic strains. These acts of hospitality and caring are acts of $u b u n t u$ in the community.

Their spiritual and religious activities are also acts of $u b u n t u$ because it is a way of celebrating who they are as people through who their ancestors were. It means a connection with the past and interconnectedness with other people and their extended families that live in other countries.

\section{A female pastor}

The African Church is still growing and African Christianity has expanded enormously since the 1950s. Isichei (1995:323) comments that, although Chinua Achebe wrote his first novel based on a poem by Yeats, Things fall apart (1958) was published at a time of tremendous hope and expectancy. Between 1958 and 1964, much of Africa regained independence in what has been called a 'conspiracy of optimism' (Isichei 1995:323). Things only fell apart later on.

In most African societies, men have dominated women for a long time. There are even sayings in Africa that imply that a woman is not able to do anything without the help of a man. However, despite the manner in which women are controlled in African societies, there is an area (besides their ability to have children) where men acknowledge the dignity and giftedness of women; this area is religion. According to Oduro, Pretorius, Nussbaum and Born (2008:142), the religious roles of women in African societies are much older than the introduction of Christianity to Africa.

The churches in Africa began as, and have returned to being, 'feminine alternative societies to the male-dominated secular world' (Isichei 1995:333). The Christian faith has played a very important role to change and to improve the position of women in society. Women have returned to the centrality of the African Church and, dominate many church congregations, as in the case of the local church of Zama Zama. The 'Joy of the Lord International Ministries' is the only church in Zama Zama. 
A female pastor leads the local church in Zama Zama. She came from Zimbabwe and initially experienced jealousy and intimidation from the local people. At first, the church gatherings and services were held in a garage located next to the squatter camp. As the congregation grew in size, the church gathering moved to a tent in the community. The pastor asked God to show her how she had to reach out to the community in an attempt to gain the local people's trust. She started a crèche for the local children. By caring for the local women's children, people started to trust her.

From the conversations with these women, it became clear that the church is the place where ubuntu takes place. Members of the church community care for and respect each other. The women in the church taking a leading role also experience respect from the men in the church. In keeping with the message behind $u b u n t u$, love and compassion from each other is experienced in the church community. Women define themselves as being creatures of God with a special position in God's Kingdom; as a result, they feel important and loved.

Rakoczy's (2004:21) view is that the context of African women's theology is profoundly communal; the phrase, 'I am because we are', is only one of many ways in which African people articulate their conviction that the group is more important than the individual is.

\section{Conclusion}

This article explored $u b u n t u$ amongst marginalised women in Zama Zama in Pretoria West. Conversations with these women showed that they live in difficult circumstances characterised by poverty, violence and xenophobia. Being part of the local church light up their lives and gives them the strength to face their daily challenges. It is also in the congregation that they experienced ubuntu amongst each other.

\section{Acknowledgements Competing interests}

The author declares that she has no financial or personal relationships which may have inappropriately influenced her in writing this article.

\section{References}

Abrahamse, N., 2014, 'Een uit agt vroue in SA seksueel aangerand', Beeld, 25 June.

Ackermann, D., 1998, 'A voice was heard in Ramah: A feminist theology of praxis for healing in South Africa', in D. Ackermann \& R. Bons-Storm (eds.), Liberating faith practices: Feminist practical theologies in context, pp. 75-102, Uitgeverij Peeters, practices:

Ackermann, D. \& Bons-Storm, R. (eds.), 1998, Liberating faith practices: Feminist practical theologies in context, Uitgeverij Peeters, Leeuven.

Africa Check, 2013, Factsheet South Africa: Official crime statistics for 2012/2013 viewed 1 November 2014, from http://africacheck.org/factsheet/factsheetsouth-africa

Bacchus, D.N.A. \& Holley, L.C., 2014, 'Spirituality as a coping resource', Journa of Ethnic and Cultural Diversity in Social Work 13(4), 65-84. http://dx.doi. org/10.1300/J051v13n04_04

Bons-Storm, R. 1998, 'Putting the little ones into dialogue: A feminist practical theology', in D. Ackermann \& R. Bons-Storm (eds), Liberating faith practices: Feminist practical theologies in context, pp. 9-25, Uitgeverij Peeters, Leeuven.
Bower, C., 2014, 'The plight of women and children: Advancing South Africa's least privileged', The Annals of the American Academy of Political and Social Science privileged, The Annals of the American Academy of Political

Clandinin, D.J. \& Connelly, F.M., 2000, Narrative inquiry: Experience and story in qualitative research, Jossey-Bass (Wiley), San Francisco.

Carlson, T.D. \& Erickson, M.J. (eds.), 2002, Spirituality and family therapy, Haworth Press, New York.

Cronje, F. (ed.), 2014, 'The 80/20 report: Local government in 80 indicators after 20 years of democracy', in South African Institute of Race Relations, viewed 10 December 2014, from http://irr.org.za/reports-and-publications/occasionalreports/the-80-20-report-on-local-government

Frank, A.W., 1995, The wounded storyteller: Body, illness and ethics, University of Chicago Press, Chicago. http://dx.doi.org/10.7208/chicago/9780226260037.001.0001

Freedman, J. \& Combs, G., 1996, Narrative therapy: The social construction of preferred realities, W.W. Norton, New York.

Gade, C.B.N., 2011, 'The historical development of the written discourses on ubuntu' South African Journal of Philosophy 30(3), 303-329. http://dx.doi.org/10.4314/ sajpem.v30i3.69578

Green, M., 2013, 'The need for cushions: Trauma and resilience in the life of a refugee', International Journal of Psychoanalytic Self Psychology 8(2), 133-144. http://dx.doi.org/10.1080/15551024.2013.768752

Hankela, E., 2013, 'Rules of reciprocity and survival in negotiating ubuntu at the Central Methodist Mission in Johannesburg', Journal of Theology for Southern Africa $147,74-90$

Human, L., 2003, 'Fiction writing as metaphor for research: A narrative approach', Practical Theology in South Africa 18(3), 40-58.

Isichei, E., 1995, A history of Christianity in Africa: From antiquity to the present, William B. Eerdmans Publishing Company, Grand Rapids.

Janse van Rensburg, J., 2013, 'The psychology of poverty', Verbum et Ecclesia 34(1), Art \#825, viewed 10 September 2014, from http://dx.doi.org/10.4102/ve.v34i1.825

Koopman, N., 2007, 'Some theological and anthropological perspectives on human dignity and human rights', Scriptura 95, 177-185.

Kuzwayo, E., 1985, Call me woman, Women's Press, London.

Landau, L.B., Ramjathan-Keogh, K. \& Singh, G., 2005, 'Xenophobia in South Africa and problems related to it', viewed 2 December 2014, from http://migration.wits.ac.za

Mashau, T.D. \& Kritzinger, J.N.J. (eds.), 2014, Pavement encounters for justice: Doing transformative missiology with homeless people in the City of Tswane, AcadSA Publishing, Panorama.

Múller, J., 2004, 'HIV/AIDS, narrative practical theology, and postfoundationalism: The emergence of a new story', HTS Theological Studies 60(1\&2), 293-306. http:// dx.doi.org/10.4102/hts.v60i1/2.516

Múller, J. \& Van Deventer, W., 1998, 'African cosmology and pastoral family therapy', Missionalia 26(2), 260-271.

Neuman, W.L., 2014, Basics of social research: Qualitative and quantitative approaches, Pearson, Essex.

Ngcobo, T.E., 2014, 'Homelessness and human dignity in the City of Tswane: An encounter with personhood', in T.D. Mashau \& J.N.J. Kritzinger (eds.), Pavement encounter with personhood, in T.D. Mashau \& J.N.J. Kritzinger (eds.), Pavement encounters for justice: Doing transformative missiology with ho
the City of Tswane, pp. 84-97, AcadSA Publishing, Panorama.

Nicholas, B., 1998, 'Genetic testing: The tree of the knowledge of good and evil', in D. Ackermann \& R. Bons-Storm (eds.), Liberating faith practices: Feminist practical theologies in context, pp. 151-174, Uitgeverij Peeters, Leeuven.

Nyerere, J.K., 1968, Ujamaa: Essays on socialism, Oxford University Press, Dar es Salaam.

Oduro, T., Pretorius, H., Nussbaum, S. \& Born, B., 2008, Mission in an African way: A practical introduction to African Instituted Churches and their sense of mission, Christian Literature Fund.

Pieterse, H.J.C., 2001, Preaching in a context of poverty, transl. M. Manley, University of South Africa, Pretoria.

Rakoczy, S., 2004, In her name: Women doing theology, Cluster Publications, Dorpspruit.

Rubin, H.J., 1995, Qualitative interviewing: The art of hearing data, Sage Publications, Thousand Oaks.

Rugunanan, P. \& Smit, R., 2011, 'Seeking refuge in South Africa: Challenges facing a group of Congolese and Burundian refugees', Development Southern Africa 28(5), 705-718. http://dx.doi.org/10.1080/0376835X.2011.623919

Seedat, M., Van Niekerk, A., Suffla, S. \& Ratele, K., 2014, 'Psychological research and South Africa's violence prevention responses', South African Journal of Psychology 44(2), 136-144. http://dx.doi.org/10.1177/0081246314526831

Shutte, A., 2001, Ubuntu: An ethic for a new South Africa, Cluster Publications, Pietermaritzburg.

Tutu, D.M., 1999, No future without forgiveness, Rider, London.

United Nations, 2013, 'The millennium development goals report 2013' viewed 05 December 2014, from http://www.un.org/millenniumgoals/pdf/ report.2013

Van Huyssteen, J.W., 1997, Essays in postfoundationalist theology, William B. Eerdmans Publishing Company, Grand Rapids.

Van Huyssteen, J.W., 2006, Alone in the world? Human uniqueness in science and theology The Gifford Lectures, William B. Eerdmans Publishing Company, Grand Rapids.

Vorster, J.M., 2005, 'Christelik-etiese perspektiewe op armoedeverligting in SuidAfrika', Nederduitse Gereformeerde Teologiese Tydskrif 46(3\&4), 651-663. 